\title{
INVESTIGATIONAL ANALYSIS OF PERFORMANCE CHARACTERISTICS AND EMISSION OF CASHEW NUT SHELL BIODIESEL ON DI DIESEL ENGINE
}

\author{
V. Thanigaivelan \\ Assistant Professor, Department of Mechanical Engineering, SRM IST, Chennai, India

\section{Loganathan} \\ Associate Professor, Department of Mechanical Engineering, Annamalai University, \\ Chidambaram, India.
}

\begin{abstract}
In this study, the combustion and emission characteristics of biodiesel produced from Cashew nut shell oil and its blends and diesel fuel were compared. The experiments were performed in a single-cylinder direct injection diesel engine at steadystate conditions over the constant RPM (1500 RPM). During the experiments, the specific fuel consumption (SFC), pollutant emissions like hydrocarbon (HC), carbon monoxide (CO), oxides of nitrogen NOx) and smoke, and in-cylinder pressures were measured. The experimental results showed that, biodiesel blends had a $26.79-24 \%$ reduction in brake thermal relative to diesel fuel. On the other hand, Cashew nut shell oil biodiesel drastically increases $\mathrm{CO}, \mathrm{HC}$ and smoke, while the NOx emission decreased. The combustion analysis showed that the addition of Cashew nut shell oilbiodiesel to diesel fuel reduced the ignition delay period and also reduced the premixed peak. These results showed that Cashew nut shell oil biodiesel and its blends could be used without any modifications as an alternative fuel in diesel engine
\end{abstract}

Keywords: Methyl ester, Transesterification, Biodiesel, Combustion \&Emission

Cite this Article: V. Thanigaivelan and. M. Loganathan, Investigational Analysis of Performance Characteristics and Emission of Cashew nut Shell Biodiesel on DI Diesel Engine, International Journal of Advanced Research in Engineering and Technology, 10(1), 2019, pp 45-54.

http://iaeme.com/Home/issue/IJARET?Volume=10\&Issue $=1$

\section{INTRODUCTION}

Biodiesel is described as fatty acid methyl or ethyl esters from vegetable oils or animal fats as an alternative fuel of diesel. It is renewable, biodegradable, non-toxic and oxygenated fuel $[1,2]$. Even though many researches pointed out that it might help to decrease greenhouse gas emissions, improve income distribution and promote sustainable rural development [3-6]. The primary cause is being deficient in of new knowledge about the influence of biodiesel in diesel 
engines. For instance, the reduction of engine power, as well as the increase of fuel consumption for biodiesel, is not as a large amount as anticipated; the early research conclusions have been reserved, it is more prone to oxidation for biodiesel, which may result in mysterious gums and sediments that can plug the fuel filter, and thus it will influence engine durability $[7,8]$. In the automotive sector, the higher oxides of nitrogen (NOx) and $\mathrm{HC}$ emission from the diesel engine are its main problems with respect to air pollution. In this perspective, the reductions in $\mathrm{HC}$ and $\mathrm{CO}$ emissions from the engine can be obtained by the use of biodiesel. But, NOx emissions are slightly increased for the biodiesel blended diesel fuel [9-13]. High viscosity, surface tension and density of biodiesel influence atomization by increasing the mean fuel droplet size, which in turn increases the spray tip penetration. The higher the mean droplet size of biodiesel is because of the lower Weber number [14]. Many researchers have found that the viscosity and density are affected the atomization, whereas density is the lowest on mean droplet size and consequently to get better fuel atomization viscosity should be the first alternative of a fuel's physical property to be decreased [5-7]. The above mentioned problem can be solved by blending biodiesel with diesel fuel, which will decrease the viscosity of the fuel. India is a hot country and has a suitable climate for the development of the Java plum tree. India has potential for the growth of Java plum trees and these trees are cultivated in forests and waste lands. The growth of Java plum trees in waste lands also reduces soil erosion and lead to enhance of rain fall. The seeds obtained from Java plum trees are crushed in an explore to get the oil. The present investigation is carried out to describe the complete production process, analysis of thermo-physical properties and working characteristics of Cashew nut shell oil biodiesel in a direct injection compression ignition engine.

\section{BIODIESEL PRODUCTION AND PROPERTY ANALYSIS}

\subsection{Transesterification}

The reaction mechanism for alkali catalyzed transesterification was formulated as three steps. Transesterification is the process of conversion of the triglyceride with an alcohol in the presence of a catalyst to form esters and glycerol. Vegetable oil is subjected to chemical reactions with alcohol like methanol or ethanol in the presence of a catalyst. Since the reaction is reversible, excess methanol is required to reduce the activation energy, thereby shifting the equilibrium to the product side. The triglyceride present in the vegetable oil is converted into biodiesel. Among the alcohols used for the transesterification reaction are methanol and ethanol. However, when methanol is processed, methyl esters are formed, whereas ethanol produces ethyl esters. Both these compounds are biodiesel fuels in

different chemical combinations. The mechanism of the transesterification reaction scheme is illustrated by Fig. 1. Transesterification of rapeseed oil produces ester whose properties is comparable with those of diesel fuels. Schematic diagram of biodiesel plant is shown in Fig. 2. The properties of the diesel fuel and the Cashew nut shell oil biodiesel are summarized in Table 1.

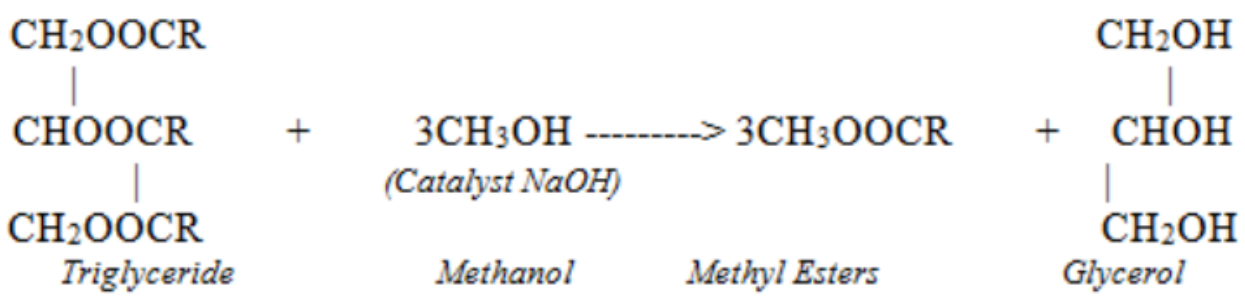

Figure 1 Mechanism of transesterification process. 


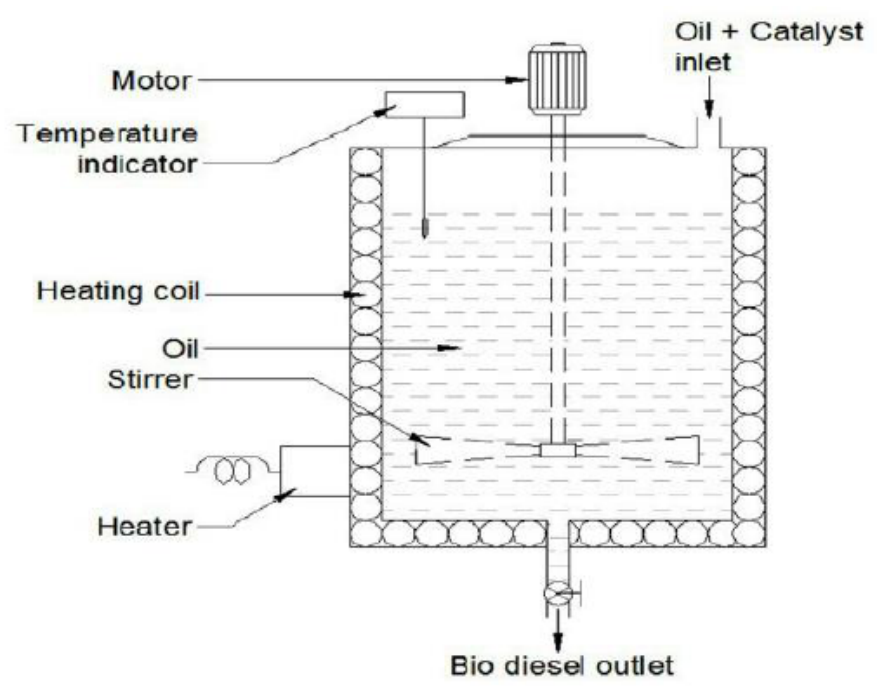

Figure 2 Schematic diagram of Biodiesel Plant.

Table 1 Properties of diesel and biodiesel blends

\begin{tabular}{|c|c|c|c|c|c|c|}
\hline \multirow{2}{*}{ Properties } & $\begin{array}{c}\text { Specific } \\
\text { gravity@ } \\
\mathbf{1 5 / 1 5}(\mathbf{C} \\
\mathbf{( G M / c c )}\end{array}$ & $\begin{array}{c}\text { Kinematic } \\
\text { Viscosity } \\
\mathbf{C} \mathbf{4 0}(\mathbf{C} \\
\mathbf{( C S T})\end{array}$ & $\begin{array}{c}\text { Flash } \\
\text { Point } \\
\left({ }^{\circ} \mathbf{C}\right)\end{array}$ & $\begin{array}{c}\text { Fire } \\
\text { Point } \\
\left({ }^{\circ} \mathbf{C}\right)\end{array}$ & $\begin{array}{c}\text { Gross } \\
\text { calorific } \\
\text { value } \\
(\mathbf{K c a l s} / \mathbf{k g})\end{array}$ & $\begin{array}{c}\text { Density } \\
\mathbf{0} \mathbf{1 5}(\mathbf{C} \\
(\mathbf{G M} / \mathbf{c c})\end{array}$ \\
\hline Diesel & 0.835 & 2.56 & 44 & 48 & 10,660 & 0.834 \\
\hline $\begin{array}{c}\text { Biodiesel } \\
100 \%\end{array}$ & 0.8996 & 5.6 & 82 & 98 & 9980 & 0.9835 \\
\hline
\end{tabular}

\section{EXPERIMENTAL SETUP}

The diesel engine used for experimentation is Kirloskar TV1, single cylinder, water cooled engine coupled to eddy current dynamometer with computer interface and it is shown in Fig. 3. The properties of diesel and cashew nut oil are given in Table 2. The detailed specification of the engine is shown in Table 3. A data acquisition system is used to collect and analyze the combustion data like in-cylinder pressure and heat release rate during the experiment by using AVL transducer. The tests are conducted at the rated speed of 1500 RPM. In every test, exhaust emission such as nitrogen oxides (NOx), hydrocarbon (HC), carbon monoxide (CO) and smoke are measured. From the initial measurement, brake thermal efficiency (BTE) and specific fuel consumption (SFC) with respect to brake power (BP) for different blends are calculated. The blends of biodiesel and diesel used were B20 and B40. B20 means $20 \%$ biodiesel fuel and 80\% of diesel fuel by volume. In order to study the effect of biodiesel blends on the engine combustion and emission characteristics, the injection timing was kept constant at $23^{\circ}$ BTDC. The effect of biodiesel blends was studied and the results were compared with neat diesel. 


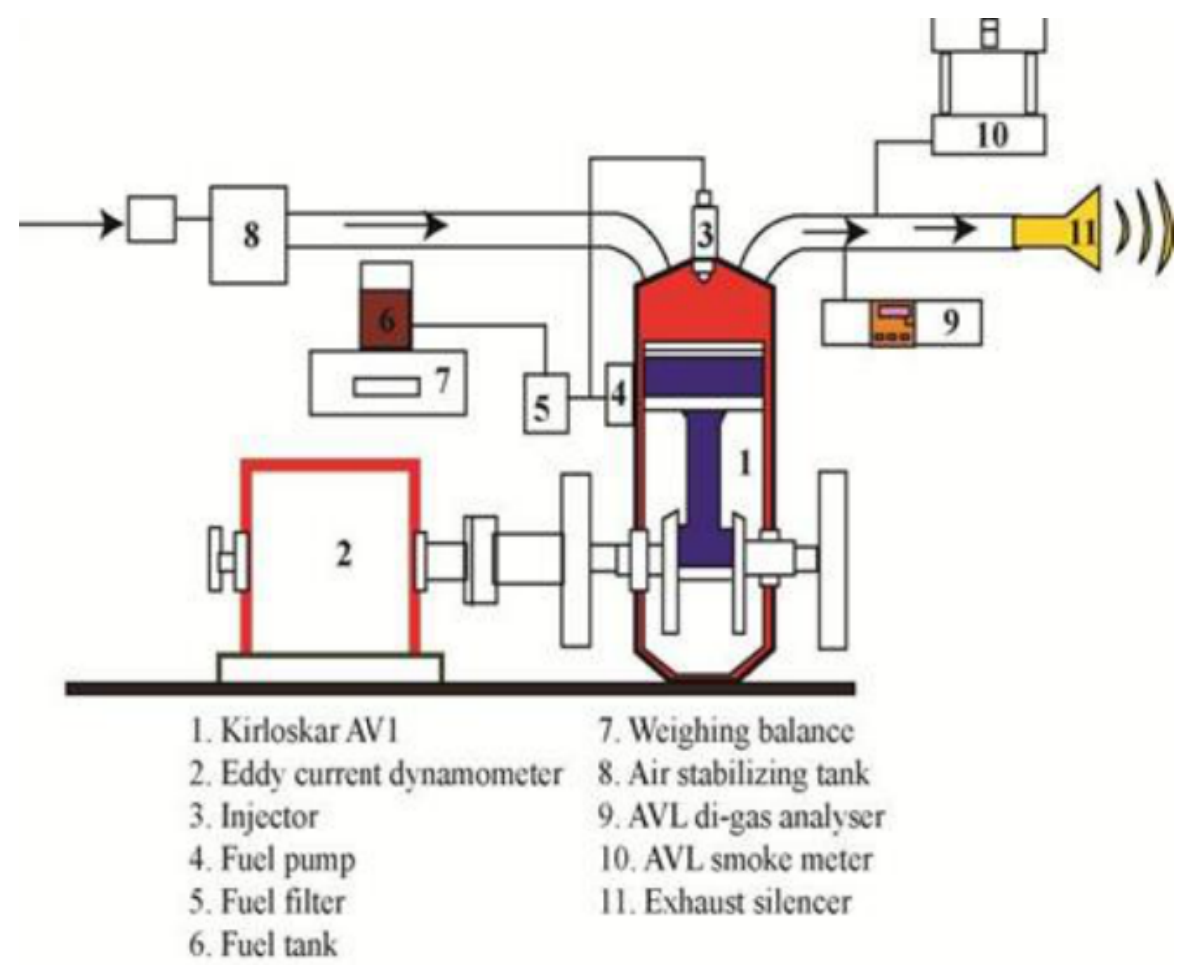

Figure 3 Schematic diagram of the experimental setup

Table 2 Properties of diesel and CNSL oil

\begin{tabular}{|c|c|c|}
\hline \multicolumn{3}{|c|}{$\begin{array}{c}\text { Properties of diesel and CNSL oil } \\
\text { (Source: ITA laboratory- chennai) }\end{array}$} \\
\hline Properties & Diesel & CNSL \\
\hline Density at (g/cc) & $0.8 / 0.84$ & 0.9326 \\
\hline $\begin{array}{c}\text { Kinematic Viscosity @ } \\
40{ }^{\circ} \mathrm{C}(\mathrm{cSt})\end{array}$ & 2.0 to 4.5 & 12.27 \\
\hline Calorific value (kJ/kg) & 47693 & 20836 \\
\hline Flash Point $\left({ }^{\circ} \mathrm{C}\right)$ & 80 & 98 \\
\hline Fire Point $\left({ }^{\circ} \mathrm{C}\right)$ & 86 & 108 \\
\hline
\end{tabular}


V. Thanigaivelan and. M. Loganathan

Table 3 Specification of test engine

\begin{tabular}{|c|c|}
\hline \multicolumn{2}{|c|}{ ENGINE SPECIFICATION } \\
\hline Make & $\begin{array}{c}\text { Vertical, Water cooled, } \\
\text { KIRLOSKAR AV-1 }\end{array}$ \\
\hline Number of cylinder & One \\
\hline Bore & $110 \mathrm{~mm}$ \\
\hline Stroke & $3.7 \mathrm{~kW}$ \\
\hline Maximum power & $17.5: 1$ \\
\hline Compression ratio & $661 \mathrm{CC}$ \\
\hline Displacement Volume & $1500 \mathrm{rpm}$ \\
\hline Speed & $23^{\circ} \mathrm{b} \mathrm{TDC}$ \\
\hline Injection opening \\
angle
\end{tabular}

\section{RESULT AND DISCUSSION}

\subsection{Performance Characteristics}

Fig. 4 shows the variations in brake thermal efficiency with respect to brake power. The Brake thermal efficiency (BTE) of neat diesel is more than other blends, i.e. B20 has lower brake thermal efficiency followed by $\mathrm{B} 40, \mathrm{~B} 60, \mathrm{~B} 80$ and $\mathrm{B} 100$ respectively. The reason may be the higher viscosity of the Cashew nut shell oil biodiesel blends that leads to poor atomization in the injector. B20 has shown better results than other blends since it has lower viscosity when compared to other biodiesel blends. The BTE of blend B20 shows an increase of $8.04 \%$ when compared to B100 at full load. 


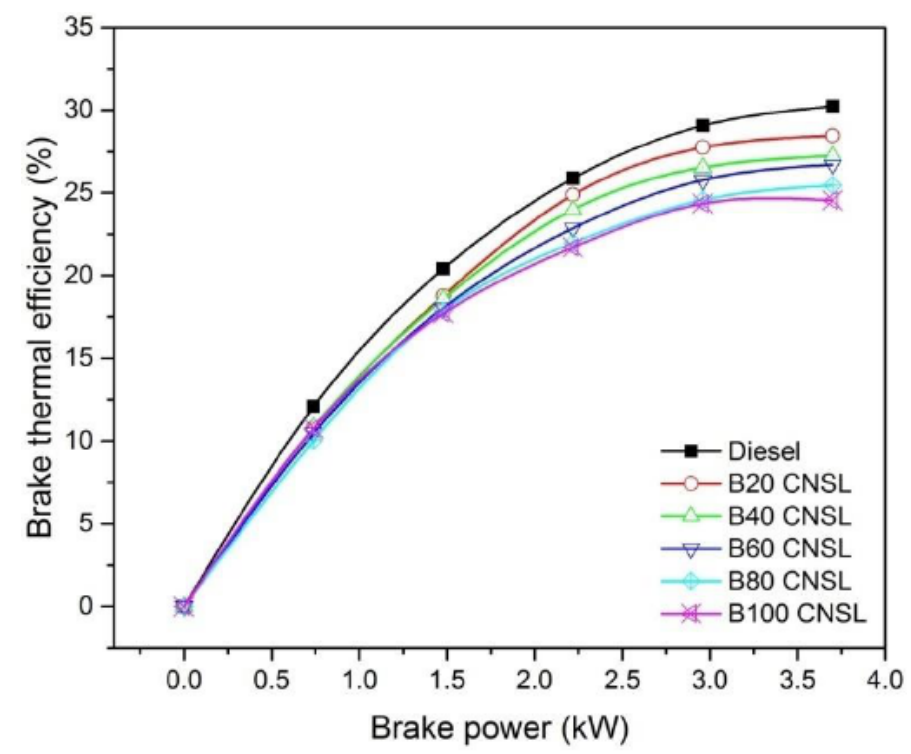

Figure. 4 Brake thermal efficiency against brake power

\subsection{Emission Characteristics}

Fig. 5 shows the variations of oxides of nitrogen with brake power. The oxides of nitrogen (NOx) emission after combustion is less in diesel fuel compared to Cashew nut shell oil biodiesel and its blends. From the graph it is clear that the NOx emission in B20, B40, B80 and $\mathrm{B} 100$ are less when compared with neat diesel. The reason is the reduced combustion temperature that prevails inside the combustion chamber due to the higher heating value of the Cashew nut shell oil biodiesel blends. The blend B100 has shown aincrease of NOxemission $6.35 \%$ when compared to that of diesel fuel at full load.

The variation in $\mathrm{HC}$ emission with brake power results is shown in Fig. 6. The HC emission was increased to 35, 27.3, 27, 24, 22 and 18 ppm for the B100, B80, B60, B40 and B20 blends, respectively. A possible explanation for the increment in the $\mathrm{HC}$ emission, when fueling with biodiesel and its blends is that lower calorific value and a certain number of the Cashew nut shell oilbiodiesel compared with the diesel fuel. The reason may cause an incomplete combustion of fuel, increase the HC emission [9,13]. The HC emission increased $26.29 \%$ compared to that of diesel when B100 used as fuel.

The variation in $\mathrm{CO}$ emission with brake power is shown in Fig. 7. An average of $1.83 \%$ and $1.33 \% \mathrm{CO}$ emission increment were observed in $20 \%$ and $40 \%$ Cashew nut shell oil biodiesel blends, respectively. $\mathrm{CO}$ emission becomes highly significant, when the cylinder temperature is low and the in-cylinder combustion is incomplete. $\mathrm{CO}$ emission for all Cashew nut shell oil biodiesel blends are in incomplete combustion. A lower cetane number of biodiesel blends exhibits a longer ignition delay and allows longer combustion duration. Then the viscosity of biodiesel comes into play, which reduce the combustion process. The CO emission was $0.28 \%$ for diesel fuel and it was reduced to $0.38 \%$ by volume when B100 used as fuel.

Smoke emission is the visible product of diesel engine emission. The comparison of smoke emission of B20, B40, B60, B80, B100 and diesel fuel with respect to brake power is shown in Fig. 8. From the graph, it is observed that smoke emission of Cashew nut shell oil biodiesel and its blends are significantly higher than that of neat diesel at all load conditions. However, when the load increases to maximum level, smoke emission is increased for Cashew nut shell oil biodiesel and its blends with diesel. The formation of local rich mixtures of fuel in the 
combustion chamber due to high viscosity and density of biodiesel blends results in poor atomization.

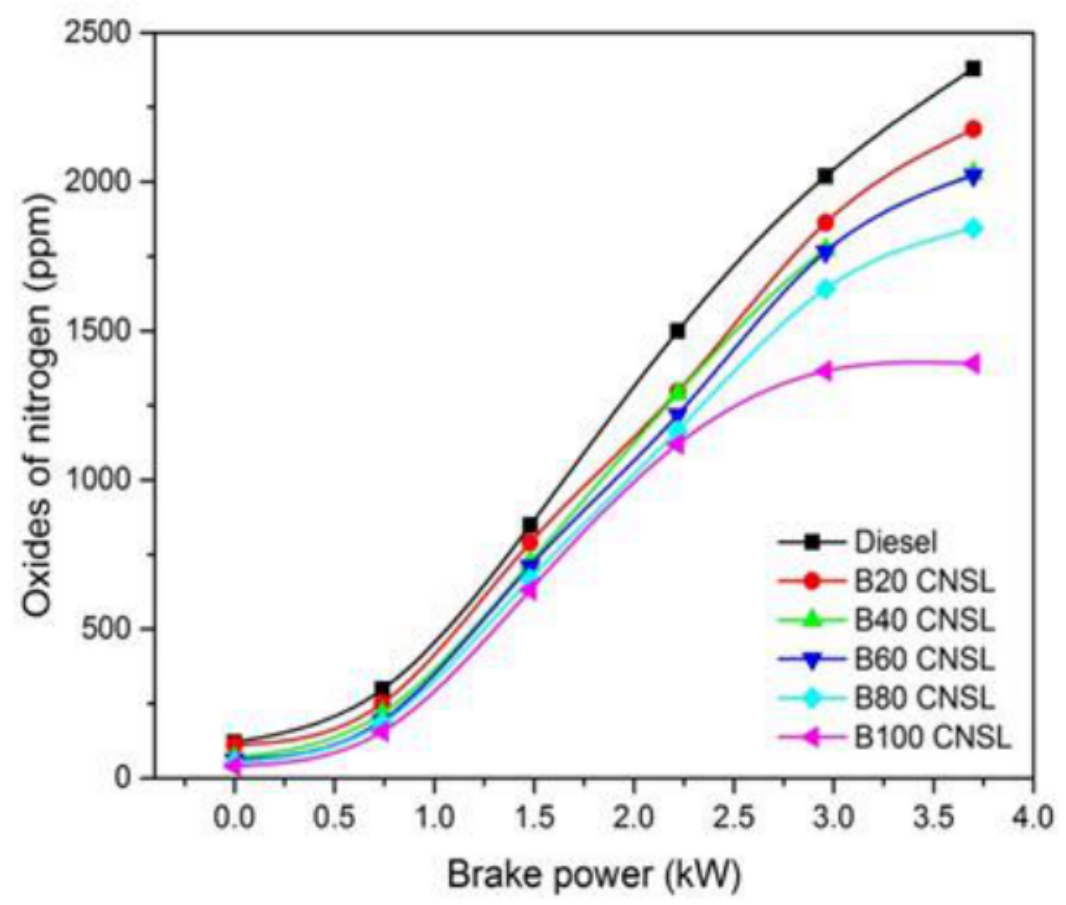

Figure 5 Oxides of nitrogen emission against brake power.

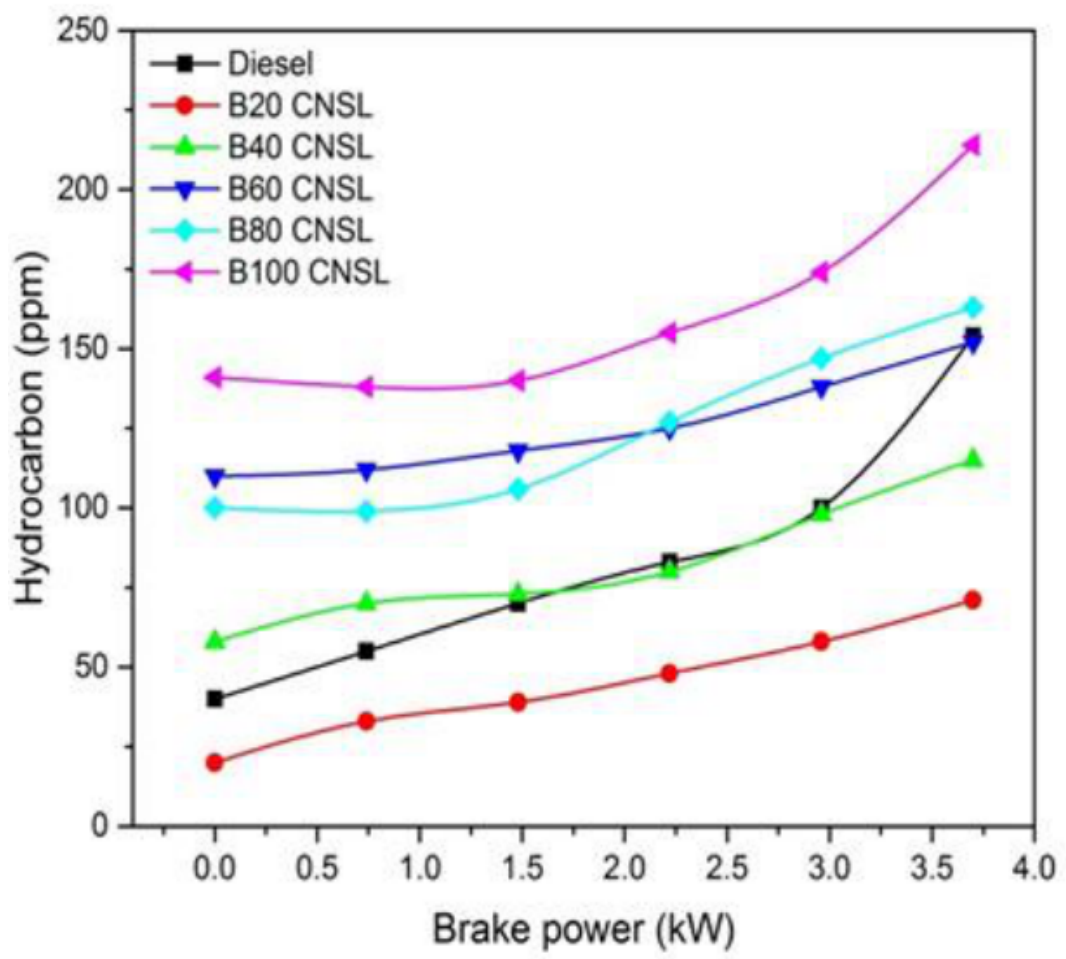

Figure 6 Hydrocarbon emission against brake power. 
Investigational Analysis of Performance Characteristics And Emission of Cashew Nut Shell Biodiesel on Di Diesel Engine

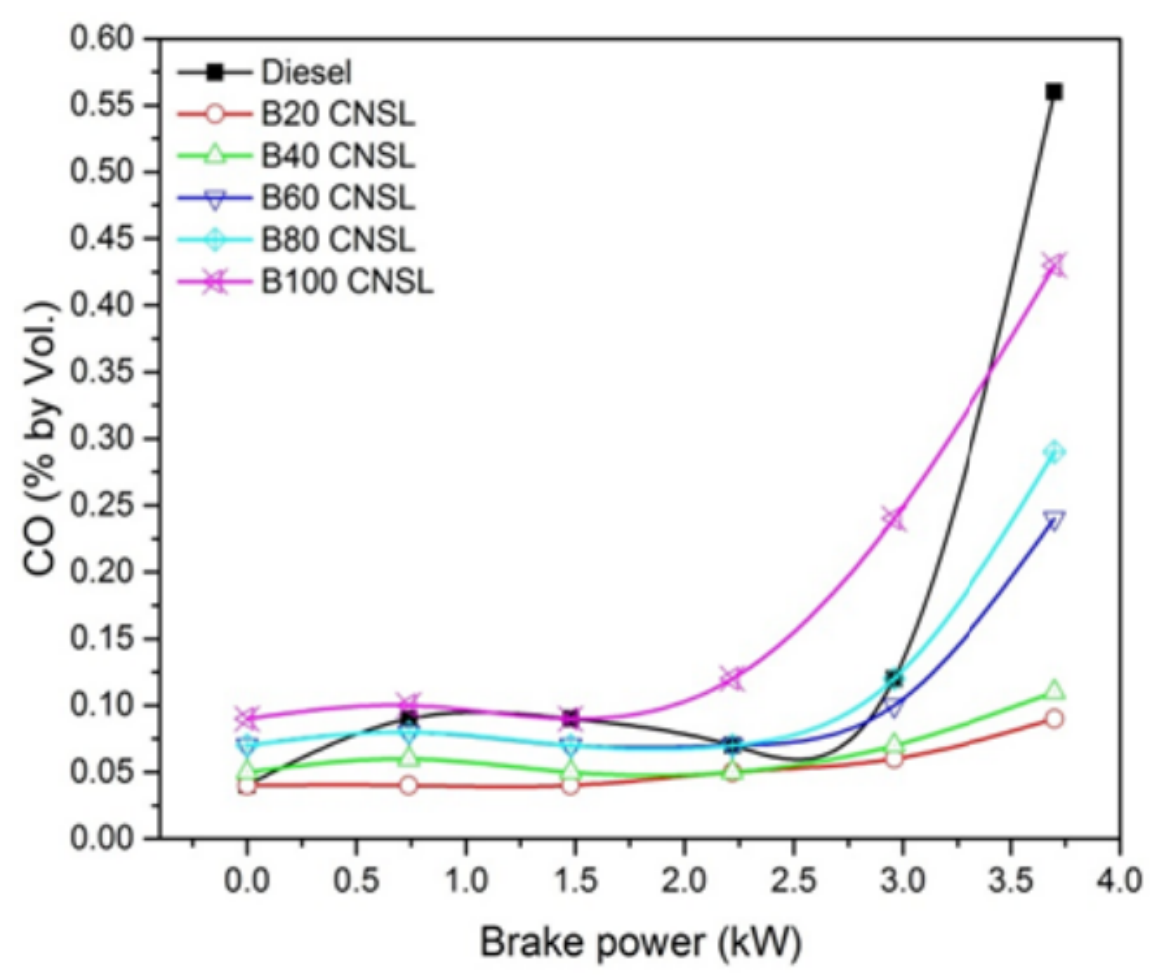

Figure 7 Carbon-monoxide emission against brake power

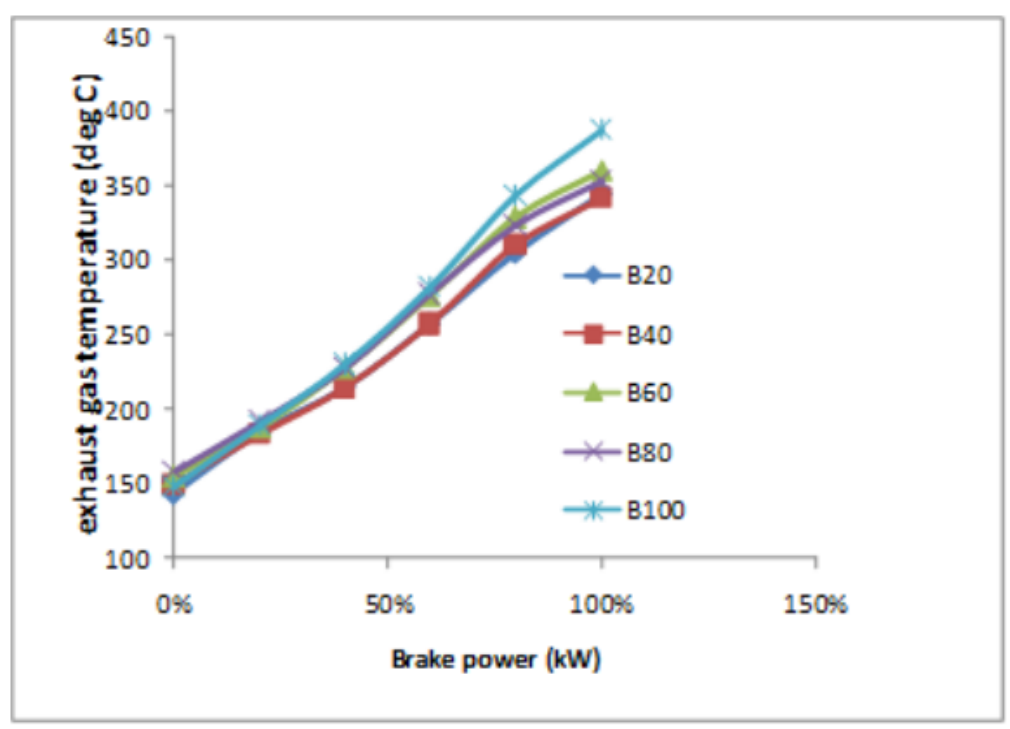

Figure 8 Specific fuel consumption against brake power.

The fig. 9 represents the variation of exhaust gas temperature and brake power of the engine. The results showed the exhaust gas temperature increased with increasing the blend ratio of the CNSL. This is due to after burning of unburned fuel in the exhaust pipe. 


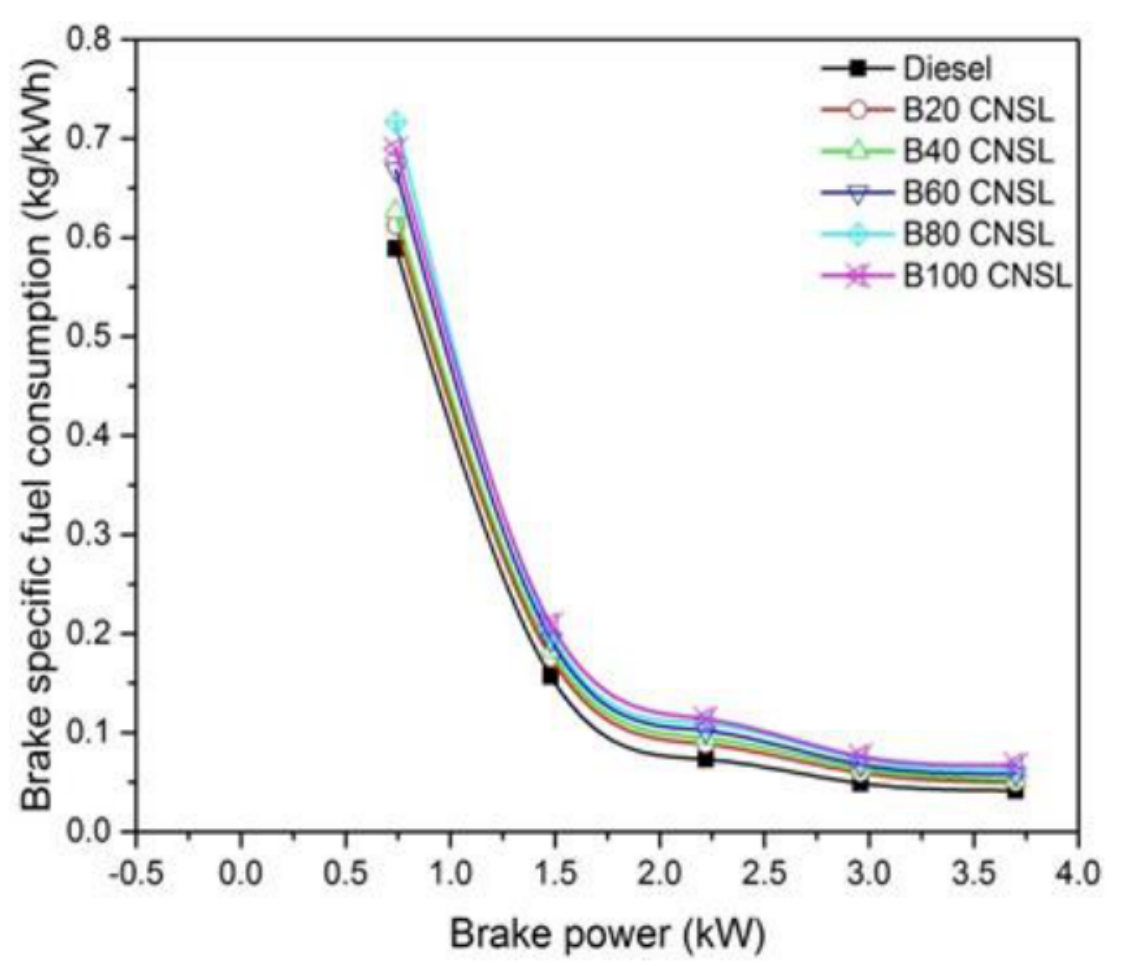

Figure 9 variation of exhaust gas temperature.

\section{CONCLUSIONS}

The following conclusions are drawn based on this experimental investigation on diesel engine when Cashew nut shell oilbiodiesel and its blends were used as fuel.

$\checkmark$ An average of 4\% BTE decrease was observed in 100\% Cashew nut shell oilbiodiesel. Viscosity, density, and a certain number of the Cashew nut shell oil biodiesel played vital role in engine performance.

$\checkmark$ An average of $0.26 \% \mathrm{CO}$ and 102 ppm HC emission increment were observed in $100 \%$ Cashew nut shell oilbiodiesel and an average of $0.16 \% \mathrm{CO}$ and $56 \mathrm{ppm} \mathrm{HC}$ emission reductions were observed for $20 \%$ blend compared with diesel fuel.

$\checkmark$ The NOx emission is decreased by $3.57 \%$ to $18.06 \%$ for the addition of $20 \%$ to $100 \%$ Cashew nut shell oilbiodiesel, respectively. Diesel fuel exhibited a moderate level of NOx emission. It was observed that higher viscosity and density are the most desirable properties of biodiesel for lower NOx emission.

$\checkmark$ Lower in-cylinder pressure and lower heat release rate was found in all the biodiesel cases.

\section{REFERENCES}

[1] L.C. Meher, D. VidyaSagar, S.N. Naik, Technical aspects of biodiesel production by Transesterification-a review, Renewable and Sustainable Energy Reviews, Volume 10, 2006, Pages 248-268.

[2] Garpen, J.V., Biodiesel processing and production, Fuel Processing Technology, Vol. 86, 2005, Pages 1097-1107.

[3] Vlada B. Veljkovic ,Ivana B. Bankovic-Ilic, Olivera S. Stamenkovic: Purification of crude biodiesel obtained by heterogeneouslycatalyzedtransesterification, Renewable and Sustainable Energy Reviews, Volume 49, 2015, Pages 500-516. 
[4] C. Syed Aalam, C.G. Saravanan: Biodiesel Production Techniques: A Review. International Journal for Research in Applied Science and Engineering Technology, Volume 3, 2015, Pages 41-45.

[5] C. Syed Aalam, C.G. Saravanan. Biodiesel Production from Mahua oil via Catalytic transesterification method. International Journal of ChemTech Research.Vol.8 (4), pp 1706$1709,2015$.

[6] A.M. Ashraful, H.H. Masjuki, M.A. Kalam, I.M. Rizwanul Fattah, S. Imtenan, S.A. Shahir, H.M. Mobarak. Production and comparison of fuel properties, engine performance, and emission characteristics of biodiesel from various non-edible vegetable oils: A review. Energy Conversion and Management, Volume 80, 2014, Pages 202-228.

[7] GauravDwivedi, M.P. Sharma, Potential and limitation of straight vegetable oils as engine fuel - An Indian perspective, Renewable and Sustainable Energy Reviews, Volume 33, 2014, Pages 316-322.

[8] Loganathan. M. Velmurgan.A, "Performance and Emission characteristics of DI Diesel Engine Fuelled with Cashew Nut Shell Liquid (CNSL) - Diesel Blends", world academy of science, Engineering and Technology Vol:5,2011.

[9] E.F. Aransiola, T.V. Ojumu, O.O. Oyekola, T.F. Madzimbamuto, and D.I.O. Ikhu-Omoregbe: A review of current technology for biodiesel production: State of the art. Biomass and Bioenergy, Volume 61, 2014, Pages 276-297.

[10] D.C. Rakopoulos, C.D. Rakopoulos, E.G. Giakoumis, A.M. Dimaratos,M.A. Founti, Comparative environmental behavior of bus engine operating on blends of diesel fuel with four straight vegetable oils of Greek origin: Sunflower, cottonseed, corn and olive, Fuel, Volume 90, 2011, Pages 3439-3446.

[11] C. Syed Aalam, C.G. Saravanan, B. PremAnand. Impact of high fuel injection pressure on the characteristics of CRDI diesel engine powered by mahua methyl ester blend. Applied Thermal Engineering 106 (2016) 702-711.

[12] I.M. Atadashi, M.K. Aroua, A.R. Abdul Aziz, and N.M.N. Sulaiman: The effects of catalysts in biodiesel production: A review. Journal of Industrial and Engineering Chemistry, Volume 19, Issue 1, 2013, Pages 14-26.

[13] M. Aarthy, P. Saravanan, M.K. Gowthaman, C. Rose, N.R. Kamini: Enzymatic transesterification for production of biodiesel using yeast lipases: An overview. Chemical Engineering Research and Design, Volume 92, Issue 8, 2014, Pages 1591-1601.

[14] Ching-Lung Chen, Jo-Shu Change, Chien-Chang Huang, Kao-Chia Ho, Ping-Xuan Hsiao, Meng-Shan Wu: A Novel Biodiesel Production Method Consisting of Oil Extraction and Transesterification from Wet Microalgae, Energy Procedia, Volume 61, 2014, Pages 12941297.

[15] Biju Cherian Abraham and Alvin K.S. Effect of Additive and Raw Rubber Seed Oil Mixture in A Biodiesel. International Journal of Advanced Research in Engineering and Technology, 6(8), 2015, pp. 12-20.

[16] Abhishek V, Nithyananda B S, Anand A and Dr. G V Naveen Prakash, Evaluation and Comparison for Fuel Properties of Simarouba and Calophyllum Biodiesel, International Journal of Mechanical Engineering And Technology (IJMET), Volume 5, Issue 9, September (2014), pp. 217-221.

[17] Shivakumar Vasmate, Sreenuraju. M, Shashikant Kushnoore and Prasad Biradar, Experiment on Multi Blend Biodiesel Using Jatropha and Pongamia Biodiesel on Single Cylinder Diesel Engine with Base Line of Diesel Fuel. International Journal of Mechanical Engineering and Technology, 7(2), 2016, pp. 273-281

[18] N. Prabhu Kishore, Alekhya. N, J. Krishnaraj, Bridjesh. P and V.Anil Kumar, Experimental Analysis of Calophyllum Inophyllum Biodiesel Blends On Variable Compression Ratio Diesel Engine. International Journal of Mechanical Engineering and Technology, 8(7), 2017, pp. 225230.

[19] Rakesh Kumar, Maninder Singh, Prabhjot Singh and Ambe Verma Experimental Analysis of Engine Performance and Combustion Characteristics Using Dual Biodiesel Blends. International Journal of Mechanical Engineering and Technology, 8(7), 2017, pp. 1404-1410. 